\title{
Community Participation in Wildlife Management in Baturiya Sanctuary, Northwestern Nigeria
}

\author{
Karkarna M.Z. ${ }^{1 *}$ and Danjuma M.N. ${ }^{2}$ \\ ${ }^{1}$ Department of Environmental Management, Bayero University, Kano, Nigeria \\ ${ }^{2}$ Department of Geography, Bayero University, Kano, Nigeria \\ *Corresponding Author: mzkarkarna@gmail.com
}

https://doi.org/10.36263/nijest.2020.01.0169

\begin{abstract}
Human benefits from wildlife are apparently declining over decades as the extent and intensity of threat to protected areas continue. This study assessed nature of community participation in wildlife management in Baturiya Sanctuary with a view to providing information for active participation of communities in the management of this area. A total of five communities namely: Shinge (4km west), Illala (12km west), Kokiro ( $3 \mathrm{~km}$ east), Zigobiya ( $7 \mathrm{~km}$ east) and Abanaguwa (5km north) were purposively sampled based on their proximity to the sanctuary. Snowball sampling technique was used to select fifty-seven (57) participants for the survey. Questionnaire and Interview were conducted to elicit the knowledge and perspectives of participants on the role of community in wildlife management. Numerical values were analysed in percentage while chi-square was used to test the levels of participation among communities. Findings of this study indicate that only 18 of the 57 sampled participants are involved in wildlife management. It also shows that there is decrease and extinction of wildlife especially birds, primates and reptiles in the sanctuary. The study also found four categories of participants: active-voluntary, active-institutional, passive-voluntary and passive-institutional. It shows that $37.50 \%$ active and $62.50 \%$ are passive participants respectively. Benefits of community participation include control of poaching (43.85\%) and control of trade in parts of animals (25\%). Majority of the participants (83.33\%) engage in wildlife management voluntarily based on perceived benefits derived from the sanctuary. Poor governance (43.85\%) and weak community institutions (31.57\%) are the main limitations to community participation in wildlife management. This study therefore recommended that community leaders and youth should be strengthened and officially recognized as stakeholders in wildlife management and governance of natural resources in Nigeria at large.
\end{abstract}

Keywords: Sanctuary, biodiversity, migratory birds, Nigeria.

\subsection{Introduction}

Nigeria is endowed with diverse earth's resources that can guarantee sustainable economic growth and development (Danjuma, 2017). According to the International Union of Conservation of Nature, Nigeria has a total of 309 threatened species in the the following taxonomic categories: Mammals (26), Birds (19), Reptiles (8), Amphibians (13), Fishes (60), Molluscs (1) and Invertebrates (14) (Sedghi, 2013). This provides diverse socio-economic and ecological functions to support livelihoods in the country. Over the years, these resources are highly threatened by unprecedented land use changes resulting from the needs of a burgeoning population to expand farms, illegal activities such as logging, poaching and deforestation (David, 2008; Al-Amin, 2013; Ola and Benjamin, 2019). This has created enormous problems and substantial holes in the path of sustaining Nigeria's natural resources base. In Nigeria some iconic biodiversity habitats remain important centres of species conservation and protection (Ezebilo and Mattsson, 2010; UNEP-WCMC, IUCN and NGS, 2018). Such areas include Kainji Lake (Fingesi et al., 2019), Kamuku (Abdulkadir, 2015), Falgore (Badamasi, 2014), Baturiya (Blench, 2013) as well as Gashaka-Gumti (Yager et al., 2018) which have recorded significant 
achievements despite serious challenges and especially the adoption of approach that tends to exclude local communities.

The Baturiya wetland for instance is crucial because of its unique fauna and flora and a huge collection of terrestrial, arboreal and aquatic species (BirdLife International, 2015). The Sanctuary is a protection area under the RAMSAR convention (Ramsar Bureau, 1994). It is unique interms of flora and fauna diversity including endemic primates, fishes, toads, snakes and most importantly birds of various categories. The majority of the migratory birds found in the sanctuary are from Europe, Latin America and Asia in addition to several indigenous species (Ringim et al., 2015). The sanctuary has remained bountiful and hotspots of birds' diversity for decades until recently when the status of species has significantly dwindled (Oduntan et al., 2010). Olalekan et al. (2014) reported that local communities continue to invade parts of the Baturiya sanctuary for settlements, farming, cattle grazing and fishing, as well as exploitation of the natural resources. Other resources include firewood, Doum palm, fish, and many waterfowls being illegally hunted for live trade such as ibises, storks, jacanas, and spur-wing geese, while many people engage in egg collection during the breeding season (Ogunkoya and Dami, 2007; Blench, 2013).

Beyond anthropogenic influences, the colonial era policies of centralization have also undermined biodiversity conservation in rural African landscapes (Neumann, 1998). Colonization by European powers and the accompanying spread of their conservation practices did not encourage traditional rights (Roe et al., 2009). However, the American approach of pristine wild conservation practices suffered setbacks due to rise of community-based approaches in the 1980s (Chambers, 1997). The widespread adoption of community participation in the 1980s began to be disillusioned the view that communities in Africa were behind the worsening conditions of biodiversity in different ecological and cultural settings (Diaz et al., 2006). Various studies have shown that success in conservation is often predicated by local support which is influenced by perceptions of the impacts that are experienced by local communities and opinions of management and governance (Bennett and Dearden, 2014). Engagement with diverse groups is now being increasingly considered as essential for natural resources conservation on the landscape scale in both developed and developing countries (Vos et al., 2001).

The emergence of community participation in Nigeria has played a key role in shaping initiatives in community-based wildlife management in forest neighboring communities. However, despite the long-lived intention by the government to enhance community participation, there is still inadequate involvement of people in decision making regarding protected areas in Nigeria (). The non-involvement of communities in decision making process often causes the people to lose interest in government conservation programmes, which increases over exploitation of resources. There have been relatively few cases of communities obtaining rights over resource use in Nigeria. According to Federal Government of Nigeria (2015) low public awareness on biodiversity conservation and lack of capacity for law enforcement agents to deal with issues of concern has remained relatively fundamental challenge to conservation of natural resources in Nigeria. Neglecting local communities in management itself is a threat to the areas. It can lead to deliberate (illegal) actions that can be detrimental to the protected area resources as well as a setback to the sustainability of the areas (Holmes, 2013).

Empirical evidences have shown nuanced picture of the long-term engagement and strong relationships of local people living around protected areas and wildlife. However, the strong positive relationship is now dwindling thereby undermining the future of fauna which is appearing bleak (Saidu, 2017). Similar reports showed that several villages have engaged in hiring farmlands outside their once owned lands to rice farmers who want to cling to the recent Jigawa State campaign of cluster rice initiative which significantly affects the status and diversity of wildlife in Baturiya area over the last 5 years. Although plethora of works were carried out on species composition and diversity in Baturiya sanctuary (Babura, 2015; Ringim et al., 2015; Zakari, 2015), there appears to be insufficient data and information on the role of communities in wildlife management hence few attempts were made to develop mechanisms to promote greater participation among communities located around the area. Despite the obvious contribution of biodiversity to rural livelihood, there is currently no comprehensive and reliable data on community participation in wildlife in Nigeria. This study was conducted to assess the roles of local 
people in wildlife management in Baturiya Sanctuary, northwestern Nigeria with a view to providing information for developing new strategies for successful re-connection of the communities with the once beautiful natural endowment.

\subsection{Study area}

Baturiya Wetlands Game Reserve is located in the northeast of Jigawa State, Nigeria (Figure 1). It lies on latitude $12^{\circ} 31^{\prime} \mathrm{N}$ and $12^{\circ} 39^{\prime} \mathrm{N}$ and longitude $10^{\circ} 29^{\prime} \mathrm{E}$ and $10^{\circ} 31^{\prime} \mathrm{E}$. It covers an area of $1010.95 \mathrm{~km}^{2}$. The reserve is located in Kiri Kasamma LGA and covers an area of 320 sq. km with a buffer zone of a half kilometre. It stretches along the Kafin Hausa River, to the west of the Hadejia Nguru Wetlands. Baturiya Bird Sanctuary provides a natural habitat for over 378 species of migratory birds from places as far as Europe and Australia (BirdLife International, 2015). The area is an important bird nesting and breeding ground which lost its significance owing to encroachment and neglect by authorities.

The climate of the wetland is characterized by two distinct seasons; wet (May-September) and dry season (October-April), rainfall is between $500-600 \mathrm{~mm}$, whereas temperature ranges from $12^{\circ} \mathrm{C}$ during harmattan season (cold) to about $40^{\circ} \mathrm{C}$ during hot season, rainfall is between $500-600 \mathrm{~mm}$, with mean minimum temperature of $12^{\circ} \mathrm{C}$ during the month of December to January, to a maximum of $40^{\circ} \mathrm{C}$ during the month of April (Ogunkoya and Dami, 2007). The ecosystem comprises permanent lakes and seasonally flooded pools connected by a network of channels. The ecosystem is an important site for biodiversity, especially migratory water birds from Palearctic regions. The area uses to harbor populations of 15 migratory birds of European descend (Ringim et al., 2015).

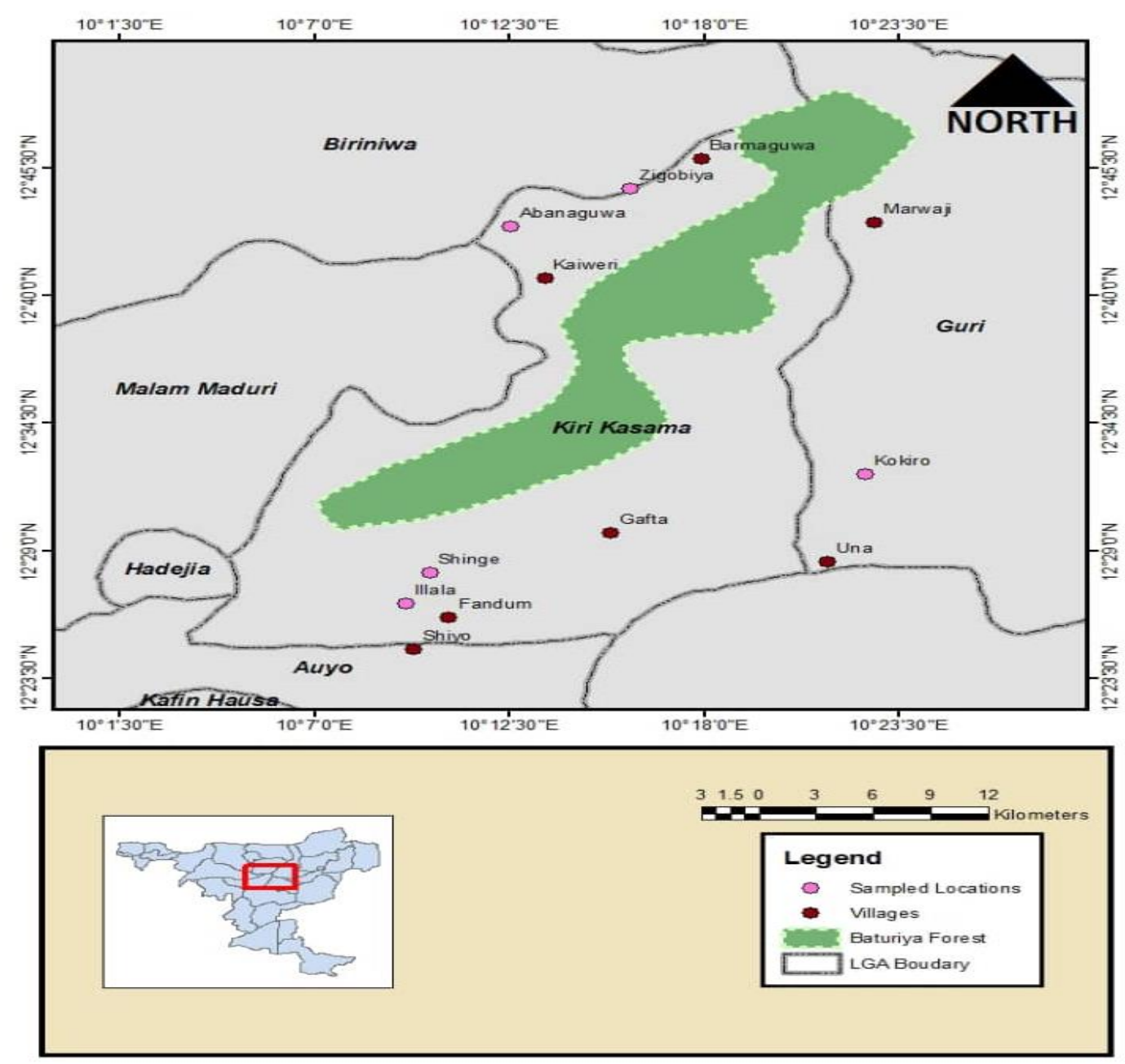

Figure 1: Map of Baturiya sanctuary, northwestern Nigeria 


\subsection{Research Methods}

The Baturiya sanctuary is surrounded by many communities that rely heavily on natural resources for a living. The study area covered all communities located within $12 \mathrm{~km}$ radius of the sanctuary namely Gafta (6km west), Shiyo ( $5 \mathrm{~km}$ southwest), Shinge (4km west), Illala (12km west), Fandum $(11 \mathrm{~km}$ west), Kaiwari (4km north), Kokiro ( $3 \mathrm{~km}$ east), Marawaji (4km east), Zigobiya ( $7 \mathrm{~km}$ east), Una ( $3 \mathrm{~km}$ east), Barmaguwa (5km east), and Abanaguwa (5km north) as sampling frame. However, Shinge, Illala, Kokiro, Zigobiya and Abanaguwa were purposively sampled. Snowball sampling technique was used to select fifty-seven participants for the survey. These fall into: Fourty eight male of between 24 and 62 years old and nine females $(15.79 \%)$. Quantitative and qualitative data were obtained from questionnaire and interview. Numerical values were analysed in percentage while qualitative data was sorted, coded and presented in textual form. Chi-square was also used to test the levels of participation among communities.

Table 1: Socio-demographic Characteristics of Participants

\begin{tabular}{clccc}
\hline SN & Study location & Total No. of Participants & No of males & No of females \\
\hline 1 & Shinge & 7 & 5 & 2 \\
2 & Illala & 9 & 9 & 0 \\
3 & Zigobiya & 16 & 13 & 3 \\
4 & Kokiro & 11 & 9 & 2 \\
5 & Abanaguwa & 14 & 12 & 2 \\
& Total & 57 & 48 & 09 \\
& $(\%)$ & 100 & 84.21 & 15.79 \\
\hline
\end{tabular}

\subsection{Result and Discussion}

Biodiversity conservation ranked 14 and 15 in the sustainable development goals yet Nigeria's effort in this regard remains frustratingly weak partly due to relegation of communities in decision-making process. This section presented results and discussions on issues relating to wildlife management in Baturiya Sanctuary, Jigawa State, Nigeria

\subsection{Local perception on status of wildlife in the sanctuary}

Biodiversity is an important source of livelihoods and income generation to communities worldwide. Status of species has been an indicator of ecosystem's health and vital ingredient for protection and sustainable management of the flora and fauna of an area. Traditional knowledge however is vital for conservation of species in protected areas. Findings of this study on status of wildlife around baturiya sanctuary have shown nuanced perceptions where $8 \%$ of the participants indicated that reptiles and rodents are observed to be increasing (Table 2). It further showed that there is significant decrease and extinction of wildlife especially birds and reptiles.

Table 2: Status of wildlife

\begin{tabular}{lccc}
\hline \multirow{2}{*}{ Wildlife categories } & \multicolumn{3}{c}{ Status } \\
\cline { 2 - 4 } & Increasing & Decreasing & Extinct \\
\hline Primates & 0 & 6 & 2 \\
Birds & 0 & 22 & 2 \\
Reptiles & 1 & 16 & 0 \\
Rodents & 4 & 4 & 0 \\
Total & 05 & 48 & 04 \\
Percentage & 8.77 & 84.21 & 7.02 \\
\hline
\end{tabular}


The work of David (2008) and Fingesi et al. (2019) have corroborated the research findings that there are substantial decline in wildlife in Nigeria's protected areas. Similarly, researchers have shown that despite the number of protected areas in Nigeria, their management status remains questionable (Abdulaziz et al., 2015), hence in practice most protected areas are referred to as "paper parks" (IUCN, 1998).

\subsection{Level of community participation}

Protected areas still have value regarding wildlife conservation especially because of growing awareness of the close links between biodiversity loss and human population growth. Table 3 present the distribution of participants by levels of participation in management of wildlife in Baturiya sanctuary. The table reveals that few respondents (28.07\%) engaged in wildlife management which suggests a low level of participation. The participants indicated that there is variation in community engagement, and they were not carried along in major decision-making regarding the use and management of wildlife and land despite their closeness to the sanctuary.

Federal Government of Nigeria (2015) reported that the National Parks that are repository of much of the country's biodiversity have faced serious threats of poaching in recent years, losing not only wildlife but also rangers. The reported indicated that biodiversity related laws are broken openly in the face of low public awareness on biodiversity conservation and lack of capacity for law enforcement agents to deal with issues of concern. This work corroborated Chirenje et al. (2013) and Isougo and Obioha (2015) who reported that if communities living close to protected areas (who believed that they should receive higher benefits than those who do not live far) are alienated from use and participation in resources governance, there will be lack of commitment to any programme aimed at conservation of the areas. Similarly, Oladeji and Fatukasi (2017) reported low participation (25\%) in Osse River Park despite huge investment in park protection and surveillance. In all the communities, majority of the participants $(60 \%)$ had not participated in wildlife management except Shinge where there is harmonious relationship between the village head and the local people.

Table 3: Level of Participation in Wildlife Management

\begin{tabular}{lcccc}
\hline \multirow{2}{*}{ Study locations } & \multicolumn{2}{c}{$\begin{array}{c}\text { No. of participants that do not } \\
\text { engage in wildlife management }\end{array}$} & $\begin{array}{c}\text { No. of participants who take part } \\
\text { in wildlife management }\end{array}$ \\
\cline { 2 - 5 } & $\mathrm{N}$ & $\%$ & $\mathrm{~N}$ & $\%$ \\
\hline Shinge & 4 & 57 & 3 & 43 \\
Illala & 7 & 78 & 2 & 33 \\
Zigobiya & 12 & 86 & 4 & 14 \\
Kokiro & 9 & 81 & 2 & 18 \\
Abanaguwa & 9 & 64 & 5 & 36 \\
Total & 41 & & 16 & \\
\hline
\end{tabular}

\subsection{Nature of participation}

Nature of participation is essential in achieving sustainable integration of communities in the management of protected areas in Nigeria. This study found two categories of participants in wildlife management in the study area namely: active/passive and voluntary/institutional (Table 4). The findings indicated that majority $(62.5 \%)$ are passive $(81.25 \%)$ and voluntarily participants. Evidently the weak performance of communities in the area is due to the fact that local people view wildlife resources as belonging to the State and they do not have the right to use wildlife directly while others have. This work showed in significant variation in the nature of participation of category two among the villages. Chi square value for active and passive (0.67) as well as voluntary and institutional (1.02) participations 
are not significant at $p<.05$ (Table 4). Hence there is no significant variation in the nature of participation among the communities. In Nigeria, Sam et al. (2014) showed that as a result of high level of active participants in conservation organization, areas of high biodiversity in Cross River Parks have regained their species composition.

Table 4: Categories of Participation in Wildlife Management

\begin{tabular}{lcccccccc}
\hline & \multicolumn{8}{c}{ Types of Participation } \\
\cline { 2 - 9 } Study locations & \multicolumn{7}{c}{ Category $1(\mathrm{n}=16)$} & \multicolumn{5}{c}{ Category 2 (n=16) } \\
\cline { 2 - 10 } & Active & $\%$ & Passive & $\%$ & Voluntary & $\%$ & Institutional & $\%$ \\
\hline Shinge & 1 & 6.25 & 2 & 12.5 & 3 & 18.75 & 0 & 0.0 \\
Illala & 1 & 6.25 & 1 & 6.25 & 2 & 12.5 & 1 & 6.25 \\
Zigobiya & 1 & 6.25 & 3 & 18.75 & 4 & 25.0 & 0 & 0.0 \\
Kokiro & 1 & 6.25 & 1 & 6.25 & 1 & 6.25 & 1 & 6.25 \\
Abanaguwa & 2 & 12.5 & 3 & 18.75 & 3 & 18.75 & 1 & 6.25 \\
Total & 6 & 37.5 & 10 & 62.5 & 13 & 81.25 & 3 & 18.75 \\
$\mathrm{X}^{2}$ & & 0.67 & & & & 1.02 & \\
\hline
\end{tabular}

This finding is in line with Murombedzi (1999) who reported that communities in Zimbabwe continued to view wildlife resource as belonging to the Rural District Councils or State and were thus focusing on land-uses that are incompatible with wildlife. Barrow et al. (2001) reported that overwhelming majority of participants in natural resources management in East Africa is passive and most time voluntary. Skidmore et al. (2006) have indicated that for effective engagement and improved community participation, that local people should not be forced but rather be given opportunity to participate and involve in projects which affect their lives.

\subsection{Benefits of community participation in wildlife management}

Local communities bear the brunt of fence and fine hence poaching and the conversion of land to more profitable land uses is on the rise in the area. Generally, wildlife products are traded in local markets (e.g. bushmeat) and internationally (e.g. animal parts for medicines). Table 5 shows the distribution of participants on wildlife management. The table indicated that majority of the participants $(75 \%)$ combats poaching of wildlife in the area. According to the participants poaching has been so limited to particular areas beyond the village boundaries of the neighboring communities. There is also restriction to trade in parts of animals.

Table 5: Direct Wildlife-related Benefits of Community Participation

\begin{tabular}{lcc}
\hline Benefits & Total Number of Participants & $\%$ \\
\hline Control of poaching & 12 & 75 \\
Control of trade in parts of animals & 4 & 25 \\
Total & 16 & 100 \\
\hline
\end{tabular}

In line with Obour et al. (2016) community anti-poaching activities in Mole National Park (MNP) Ghana have impacted positively on the general numbers of the fauna species, especially the large mammals. It has lessened the levels of poaching in the park resulting in reduced illegal activities and an increase in large mammal numbers. Communal Area Wildlife Conservancies in Namibia are 
considered a major success story as the result of reduced illegal wildlife use and recovery of game populations (Weaver and Petersen, 2008).

\subsection{Factors limiting participation in wildlife management}

Local participation in biodiversity management and enhancement of community livelihoods is limited by factors such as poor governance and weak land and resource tenure as well as community institutions and policies. Table 6 identifies three key challenges to community participation in wildlife management in the area. It shows that poor governance (43.85\%) and weak community institutions (31.57\%) are the most limiting factors of community participation in the area.

Table 6: Key Challenges of Participation in Wildlife Management

\begin{tabular}{lccc}
\hline \multirow{2}{*}{ Study Locations } & \multicolumn{3}{c}{ Factors $(\mathrm{n}=57)$} \\
\cline { 2 - 4 } & Poor governance & Insecurity & Weak Community Institutions \\
\hline Shinge & 71.42 & 28.57 & 0.00 \\
Illala & 55.55 & 22.22 & 22.22 \\
Zigobiya & 18.75 & 25.00 & 56.25 \\
Kokiro & 63.63 & 27.27 & 9.09 \\
Abanaguwa & 35.71 & 21.43 & 42.85 \\
\hline
\end{tabular}

This finding corroborates Barrett et al. (2001) who reported that weakness of existing institutions at all levels including community was the greatest challenge for achieving sustainable tropical biodiversity conservation. Zyambo (2018) also concluded that poor governance is a major limitation to natural resources management in Zimbabwe. The increased participation of local communities, NGOs and private companies in wildlife management and forest activities in the sub-region is seriously impeded by inappropriate official policies and deficient and by the lack of capacities and resources (Zeba, 1998).

\subsection{Conclusions}

This work highlights the nature of role of communities in management of wildlife through diverse practices in Baturiya sanctuary. The work reveals the communities still participate both actively and passively in wildlife management and that their actions were typically not destructive to nature. Most communities around the sanctuary as noted contributed to the preservation of primates and reptiles hence their population is significantly high. This study recommended that a new strategy should be developed to improve engagement among stakeholders in wildlife management based on the understanding that the government programmes and policies cannot be successful if community participation is missing. A model should be developed to strengthen community leaders and youth capacities and officially recognized them as stakeholders in wildlife management and governance of natural resources in Nigeria at large. Strict laws should be in place to prevent hunting or poaching of wildlife in the sanctuary area and more so communities should be involved in the management process.

\section{References}

Abdulaziz, H., Johar, F., Majid, M.F. and Medugu, N.I. (2015). Protected Area Management in Nigeria: A Review. Jurnal Tecknologi, 77:15 (2015) 31-40 
Abdulkadir, I.W. (2015). Community Participation in the Management of Kamuku National Park, Birnin Gwari LGA, Kaduna State, Nigeria. Unpublished PhD Thesis, Ahmadu Bello University, Zaria

Al-Amin, M.A. (2013). Place Biodiversity in Ecosystems' Efficiency in Nigeria. British Journal of Earth Sciences Research, Vol.1 (1): 10 -17

Anthony, M.L., Knuth, B.A. \& Lauber, T.B. (2004). Gender and citizen participation in wildlife management decision making. Society \& Natural Resources, 17:395-411.

Badamasi, M.M. (2014). An Integrated Approach to the Assessment of Changes in Vegetation Cover in Falgore Game Reserve, Kano State, Nigeria. Unpublished PhD Thesis submitted to the Department of Geography, Usmanu Danfodio University Sokoto, Nigeria

Barrow, E., Gichohi, H. \& Infield, M. (2001). The evolution of community conservation policy and practice in East Africa. In: Hulme, D. and Murphree, M. (Edn.). African Wildlife and Livelihoods: The Promise and Performance of Community Conservation. James Currey, Oxford and Heinemann, New Hampshire.

Barret, C.B., Brandon, K., Gibson, C. and Gjertsen, H. (2001). Conserving tropical biodiversity amid weak institutions. Bio Science, 51(6): 497-502

Bennett, N.J. and Dearden, P. (2014): Why local people do not support conservation: Community perceptions of marine protected area livelihood impacts, governance and management in Thailand. Marine Policy 44: 107-116

BirdLife International (2015). Important Bird Areas factsheet: Hadejia-Nguru wetlands. Cambridge, United Kingdom.

Blench, R. (2013). An overview of the context of the Jewel project: Access rights and conflict over Common pool resources in the Hadejia-Nguru wetlands. A report prepared for the JEWEL project in the Hadejia-Nguru wetlands, report of ITAD, Cambridge CB1 2AL, United Kingdom.

Chambers, R. (1997). Whose Reality Counts? Putting the First Last. ITDG Publishing, London.

Campbell, C. \& McLean, C. (2002). Ethnic identities, social capital and health inequalities: factors shaping African-Caribbean participation in local community networks in the UK. Social Science \& Medicine, 55: 643-57.

Chirenje, L.I., Giliba, R.A. \& Musamba, E.B. (2013). Local communities' participation in decisionmaking processes through planning and budgeting in African countries. Chinese Journal of Population Resources and Environment, 11:1, 10-16, DOI: 10.1080/10042857.2013.777198

Danjuma, M.N. (2017). Vegetation Change in the Dryland of northwestern Nigeria and its Implications on Indigenous Plants. Unpublished PhD Thesis submitted to the Department of Geography, Bayero University, Kano

David, M. (2008). 118/119 Biodiversity and Tropical Forest Assessment for Nigeria. USDA Forest Service/International Forestry for USAID/Bureau for Africa.Washington, DC.

Davies, J. (2017). Biodiversity and the Great Green Wall: managing nature for sustainable development in the Sahel. Ouagadougou, Burkina Faso: IUCN.

Díaz, S., Fargione, J., Stuart Chapin, F. III, \& Tilman, D. (2006). Biodiversity loss threatens human well-being. PLoS Biol., 4(8): e277. DOI: 10.1371/journal. pbio.0040277

Dickinson, E.C. (2003). The Howard and Moore Complete Checklist of the Birds of the World. $3^{\text {rd }}$ edition. Christopher Helm, London. 
Ezebilo, E.E. \& Mattsson, L. (2010). Socio-Economic Benefits of Protected Areas as Perceived by Local People around Cross River National Park: Nigeria. Forest Policy and Economics, 12(3): 189193.

Fingesi, I.U., Tyowua, B.T., Fajobi, E. A. \& Jamilu, S.M. (2019). Species Richness and Diversity of Birds in Kainji Lake National Park, Nigeria. World News of Natural Sciences, 22 (1-11).

Holmes, G. (2013). Exploring the relationship between local support and the success of protected areas. Conservation and Society, 11(1): 72-82.

Isiugo, P.N. \& Obioha, E.E. (2015). Community Participation in Wildlife Conservation and Protection in Oban Hills Area of Cross River State, Nigeria. Journal of Sociology and Social Anthropology, 6:2, 279-291, DOI: 10.1080/09766634.2015.11885668

IUCN (1998). United Nations List of Protected Areas. Prepared by WCMC and WCPA. IUCN, Gland, Switzerland and Cambridge.

Murombedzi, J.C. (1999). Devolution and stewardship in Zimbabwe's CAMPFIRE programme. Journal of International Development, 11(2): 287-293.

Neumann, R. (1998). Imposing Wilderness: Struggles Over Livelihood and Nature Preservation in Africa, University of California Press.

Obour, R., Asare, R., Ankomah, P. and Larson, T. (2016). Poaching and its Potential to Impact Wildlife Tourism: An Assessment of Poaching Trends in the Mole National Park in Ghana. Athens Journal of Tourism, Volume 3 (3):169-192

Oladeji, S.O. \& Fatukasi, D. (2017). Participatory approach to conservation and management of protected areas in Nigeria: Case study of Osse River Park Project. African Journal of Environmental Science and Technology, Vol. 11(9):471-485

Ogunkoya, O.O. \& Dami, A. (2007). Information Sheet on Ramsar Wetlands (RIS) - 2006-2008 version: Dagona Sanctuary Lake, Hadejia-Nguru wetlands. Annual report submitted to Ramsar. Gland, Switzerland

Olalekan, E.I., Abimbola, L.M., Saheed, M. \& Damilola, O.A. (2014). Wetland Resources of Nigeria: Case Study of the Hadejia-Nguru Wetlands. Poultry, Fisheries, and Wildlife Sciences, 2:123(2-6)

Ola, O. \& Benjamin, E. (2019). Preserving Biodiversity and Ecosystem Services in West African Forest, Watersheds, and Wetlands: A Review of Incentives. Forests, 10:479; doi:10.3390/f10060479

Ramsar Bureau (1994). The Ramsar Convention on Wetlands: Convention on Wetlands of international importance especially Waterfowl Habitat. Paris, 13 July 1994. Ramsar Convention Secretariat, Gland, Switzerland.

Ringim, A.S., Abubakar, M.M., Mohammed, S.I. \& Shuaib, T. (2015). Wetland Resource Use, Conflict Management, and Conservation: Review of the Hadejia-Nguru Wetlands, Northeast Nigeria. International Journal of Innovative Science, Engineering \& Technology, Vol. 2 Issue 10

Roe D., Nelson, F. \& Sandbrook, C. (eds.) (2009). Community management of natural resources in Africa: Impacts, experiences and future directions, Natural Resource Issues No. 18, International Institute for Environment and Development, London, UK.

Saidu, Y. (2017). Protected Area Management and Biodiversity Administration. A plenary Paper Presented at the Maiden Conference of Wildlife Management Society of Nigeria (WAMSON) held in Abeokuat, 18 ${ }^{\text {th }}-20^{\text {th }}$ September, 2017 
Sam, I.E., Emeka, S. \& Etefia, T.E. (2014). Level of Community Participation in the Conservation of Natural Resources in Akamkpa Local Government Area, Southern Cross River State, Nigeria. Journal of Research \& Method in Education 4(4): 30-35

USAID (2008). Nigeria Biodiversity and Tropical Forestry Assessment - Maximising Agricultural Revenue in Key Enterprises for Targeted Sites (MARKETS) retrieved from http/pdf/usaid.go/pdf.docs

UNEP-WCMC, IUCN \& NGS (2018). Protected Planet Report 2018. UNEP-WCMC, IUCN and NGS: Cambridge UK: Gland Switzerland and Washington, DC, USA

Weaver, C. \& Petersen, T. (2008). Namibia communal area conservancies. In: Baldus, R.; Damm G. and Wollscheid, K. (eds). Best Practices in Sustainable Hunting: A Guide to Best Practices from Around the World. CIC-International Council for Game and Wildlife Conservation: Hungary

Zakari, H.H. (2015). Vegetation Composition and Conservation Status of Baturiya Wetland, Jigawa State, Nigeria. A Thesis Submitted to the School of Postgraduate Studies, Ahmadu Bello University Zaria, Nigeria

Zeba, S. (1998). Community Wildlife Management in West Africa: A Regional Review. Evaluating Eden Series Working Paper, No.9

Zyambo, P. (2018). What is Limiting Success of Community-Based Approach to Conservation of Natural Resources in Southern Africa?. Journal of Ecology \& Natural Resources, Volume 2 Issue 4

\section{Cite this article as:}

Karkarna M.Z. and Danjuma M.N., 2020. Community Participation in Wildlife Management in Baturiya Sanctuary, Northwestern Nigeria. Nigerian Journal of Environmental Sciences and Technology, 4(1), pp. 77-86. https://doi.org/10.36263/nijest.2020.01.0169 